\title{
Crime e Congresso Nacional: uma análise da política criminal aprovada de 1989 a $2006^{* *}$
}

\section{Crime and Brazil's National Congress: an analysis of the criminal policy approved from 1989 until 2006}

O presente artigo analisa a legislação aprovada em segurança pública e justiça criminal no Brasil desde 1989 até 2006. O objetivo foi analisar quais foram as políticas da união aprovadas por meio da legislação sobre o tema pelo Congresso Nacional e Executivo, problematizando duas questões: i) as direções macrossociais da punição no Brasil; ii) algumas variáveis legislativas que influenciam tais direções.

O objetivo deste trabalho, portanto, é analisar quais são as políticas de segurança pública e justiça criminal aprovadas e como estas são aprovadas no Parlamento. Tal especificidade estabelece um foco que possibilita dialogar com as interpretações produzidas até o momento sobre punição-políticas de segurança e justiça criminal a partir do banco de dados construído com as normas sancionadas no período descrito. Por essa especificidade, o trabalho não contempla uma análise das práticas e mecanismos não legais ou

\footnotetext{
Doutorando em Sociologia na Universidade de São Paulo (São Paulo, SP) e bolsista FAPESP. E-mail: marcelocampos@usp.br.

** O presente artigo é um resumo do material empírico e principais conclusões da dissertação de Mestrado Crime e Congresso Nacional no Brasil pós-1988: uma análise da política criminal aprovada de 1989 a 2006, apresentada em 2010 no Programa de Pós-Graduação em Ciência Política da Unicamp sob orientação de Valeriano Mendes Ferreira Costa e Andrei Koerner. A pesquisa foi financiada pela FAPESP e publicada em livro pelo Instituto Brasileiro de Ciências Criminais em 2010 como vencedora do $14^{\circ}$ Concurso de Monografias. Agradeço aos comentários pertinentes feitos pelos pareceristas anônimos da RBCP; por Marcos César Alvarez e Rachel Meneguello na banca de defesa; e por Angela Alonso, Brasílio Sallum Júnior e demais colegas do Seminário "Sociologia, Política e História" da USP, que discutiram versão anterior deste texto.
} 
extralegais que envolvam a segurança pública no Brasil. A análise, portanto, limita-se ao conteúdo das leis resultantes da votação final (outputs) do Parlamento brasileiro ${ }^{1}$.

Em relação ao campo teórico, dialogo criticamente com as teses sobre o recrudescimento penal no Brasil: encarceramento em massa, Estado Penal ou legislação penal de emergência ${ }^{2}$ são conceitos que possuem variações entre si. Entretanto, tais conceitos enfatizaram o aumento unilateral do poder de punir do Estado contemporâneo no Ocidente, principalmente dos anos 1980 em diante, com base na experiência dos EUA e presente em países como Inglaterra ou França. Para alguns desses trabalhos, tal fenômeno estaria sendo reproduzido pelo Brasil essencialmente por meio da aprovação de leis mais duras. Revisito brevemente parte desta bibliografia realizando um balanço interpretativo dessa discussão. Neste item descrevo as especificidades, descontinuidades, regularidades e tensões nas tentativas do controle estatal do crime $^{3}$ no Brasil pós-1988.

Por fim, após apresentar alguns dados, sinalizo como questão final que há uma coexistência entre uma legislação mais igualitária (universalista) que visou ampliar direitos e garantias fundamentais dos acusados com uma política de endurecimento penal e punitiva com a aprovação de políticas de segurança pública e justiça criminal mais reativa em relação aos acusados.

Ainda, há uma legislação neocriminalizadora que combina muitas vezes os dois elementos: a ideia de "garantir" direitos a grupos e setores da população por meio da criminalização de novas condutas (crimes resultantes de preconceito; crimes contra a exploração sexual juvenil etc.). Essas leis apontam que tais reivindicações de punição advêm muitas vezes da própria sociedade civil, do Executivo e dos parlamentares (tanto de direita como

\footnotetext{
Para cada tema, em cada legislatura, há um universo empírico enorme de proposições como apontou o trabalho de Laura Frade (2007). Em trabalho anterior demostrei tal variedade nas propostas que tramitam na Câmara dos Deputados favoráveis à redução da maioridade penal (Campos, 2009). No entanto, tais proposições são atravessadas por diferentes mecanismos do Legislativo - Comissões do Senado e Câmara, vetos do Executivo, composições partidárias dos governos etc. - que colocam questões analíticas que estão além do propósito deste texto.

Cf. Wacquant, 2001, 2002; Garland, 2001; Teixeira, 2006; Mendonça, 2006.

Durante o decorrer do texto a categoria crime será utilizada como um conceito que diz respeito a atos ilícitos codificados nas leis penais (que é o objeto da análise). Porém, como se sabe, nem todo fenômeno socialmente percebido como violento é caracterizado ou codificado como crime. Do mesmo modo, há modalidades e formas de violência que, embora estejam codificadas como crimes, não encontram enquadramento na legislação penal correspondente. Por exemplo, graves violações de direitos humanos, em alguns casos, são enquadradas como crime comum (Adorno, 2003).
} 
de esquerda). Por fim, enfatizo que essa suposta "contradição" entre tais elementos é vista neste texto como combinações de modelos punitivos, o que caracteriza uma política criminal esquizoide (para utilizar o termo de David Garland, 2001).

\section{Parlamento e política criminal: as pesquisas produzidas no Brasil}

Algumas das principais pesquisas no Brasil produzidas a respeito da política penal adotada pelo Estado brasileiro pós-1988 trabalharam com as ideias e conceitos de Estado de exceção, legislação penal de emergência ou Estado $P_{\text {Penal }}{ }^{4}$. Essas categorias e tendências foram utilizadas para designar parte significativa das políticas penais no Brasil adotadas pós-1988. Revisitando tais trabalhos é possível dividi-los em duas correntes: i) os que enfatizaram a política de segurança pública e justiça criminal ${ }^{5}$ formulada como sendo exclusivamente recrudescedora e punitivista; ii) os que pensam a coexistência entre uma política "mais dura" combinada com uma política mais garantista dos direitos e garantias fundamentais dos acusados.

De um modo geral, a pesquisa de Frade, O que o Congresso Nacional brasileiro pensa sobre a criminalidade (2007), constatou que os parlamentares apresentaram um número expressivo de propostas favoráveis ao recrudescimento dos tipos penais. Das 646 propostas de alterações dos dispositivos penais apresentadas na Legislatura 2003-2007, no Congresso Nacional, apenas 20 propostas tiveram por objeto relaxar algum tipo penal. No entanto,

\footnotetext{
4 A tese do Estado Penal de Loic Wacquant versa sobre a punição em alguns países ocidentais na atualidade. Sua teoria é colocada nos termos de um Estado que reduziu seu papel social, após a decadência do Welfare State nos EUA, Inglaterra ou França, entre outros países, ampliando a intervenção penal e endurecendo-a. A mudança do paradigma punitivo vigente até os anos 1970, para Wacquant (2001, p. 80-93), reside da contradição na qual "(...) à atrofia deliberada do Estado Social corresponde a hipertrofia despótica do Estado Penal: a miséria e a extinção de um têm como contrapartida direta e necessária a grandeza e a prosperidade insolente do outro". Essa hipertrofia do sistema carcerário (principalmente do encarceramento da população pobre) seria, portanto, característica do Estado Penal, sobretudo, nos EUA.

sistema de justiça criminal brasileiro pode ser entendido como a conexão entre as polícias (militar e civil), Ministério Público, Defensoria Pública, Judiciário e Sistema Prisional no intuito de processar as condutas capituladas como crime no Código Penal brasileiro (CP), de acordo com os procedimentos legais estabelecidos no Código de Processo Penal (CPP) (Vargas e Ribeiro, 2008). Nos países de civil Law, como o Brasil, casos semelhantes podem acarretar decisões diferentes visto que a solução anterior de um caso não produz vinculação da matéria para a decisão dos casos subsequentes. A administração da controvérsia se dá pela interpretação do diploma legal e não pela vinculação de precedentes. Assim, a interpretação dos códigos legais é realizada por quem possui autoridade dentro do sistema de justiça criminal para tal. Sobre as diferenças entre o caso brasileiro de civil Law e o common Law, ver Kant de Lima, 1999; Ribeiro, 2009.
} 
o trabalho concentrou-se sobre as propostas dos parlamentares e não sobre a legislação aprovada.

O trabalho Do sujeito de direito ao Estado de Exceção: o percurso contemporâneo do sistema penitenciário brasileiro, de Teixeira (2006), aponta que nos anos 1990 adotou-se uma política criminal de Exceção concomitante com o declínio do ideal de ressocialização do criminoso. Segundo a autora a "legislação criminal de urgência dos anos 90" inaugurou uma política criminal baseada na permanente exceção ${ }^{6}$. A adoção dessa política criminal foi resultante de um “(...) conjunto de medidas de exceção permanente em matéria de política criminal e penitenciária, [que] representou um verdadeiro ponto de inflexão em relação ao cenário dos 80" (Teixeira, 2006, p. 3).

Já, com recortes próximos a este trabalho, a pesquisa de Azevedo (2003) teve por objeto de investigação as reformas penais no Brasil e na Argentina na década de 1990 e diagnosticou uma tendência à expansão e outra à desformalização da política penal brasileira. Em direção semelhante, Mendonça (2006) teve por objeto empírico algumas das principais alterações nas leis penais do Brasil desde 1984 a 2004 e concluiu diagnosticando que há uma dualidade discursiva. Segundo a autora existem lógicas conflitantes nos modelos invocados para o controle do crime e do criminoso, pois produziram-se leis despenalizadoras (para os normalizados) e leis de recrudescimento penal (para os desnormalizados), de acordo com os termos empregados pela própria autora.

\section{Crime e Congresso Nacional: a política criminal brasileira aprovada de 1989 a 2006}

A seguir, apresento os dados coletados nesta pesquisa de acordo com algumas variáveis que serão apresentadas em relação às 84 leis aprovadas e

De forma sucinta, o Estado de Exceção nada mais é do que medidas de exceção que se transformam em regras. Para Agamben (2004), ocorre um uso do direito contemporâneo para definir o que fica de fora (excluído). De fato, essa é uma das características de nossa legislação aprovada após a redemocratização, mas certamente não a única. Uma série de práticas institucionais como a discricionariedade policial e a representação hierarquizada dos cidadãos pelas instituições e operadores da justiça criminal são algumas das questões que devem ser analisadas por meio das práticas institucionais dos atores, por exemplo, os legisladores que formulam esses dispositivos legais. Ao mesmo tempo, conforme aponto neste texto, foram aprovadas leis que visaram garantir ou ampliar os direitos e as garantias fundamentais dos acusados. Dois exemplos recentes podem ser dados para sustentar meu argumento: a Lei das Medidas Cautelares (Lei no 12.403, de 2011) que institui alternativas penais à prisão provisória; ou ainda a sanção da Lei no 12.847, de 2013, que instituiu o Sistema Nacional de Prevenção e Combate à Tortura. 
transformadas em leis ordinárias. Com relação aos partidos, estados e regiões dos proponentes, foram considerados somente os dados referentes às iniciativas de Projetos de Lei oriundos da Câmara dos Deputados e Senado Federal (o que totalizou 40 leis), excluindo as iniciativas do Executivo.

Tabela 1 - Legislação em segurança pública e justiça criminal aprovada por ano

\begin{tabular}{c|c|c}
\hline ano & frequência & $\%$ \\
\hline 1989 & 4 & 4,8 \\
\hline 1990 & 3 & 3,6 \\
\hline 1991 & 2 & 2,4 \\
\hline 1993 & 4 & 4,8 \\
\hline 1994 & 4 & 4,8 \\
\hline 1995 & 11 & 13,1 \\
\hline 1996 & 8 & 9,5 \\
\hline 1997 & 6 & 7,1 \\
\hline 1998 & 6 & 7,1 \\
\hline 1999 & 1 & 1,2 \\
\hline 2000 & 5 & 6 \\
\hline 2001 & 7 & 8,3 \\
\hline 2002 & 4 & 4,8 \\
\hline 2003 & 10 & 11,9 \\
\hline 2004 & 3 & 3,6 \\
\hline 2005 & 3 & 3,6 \\
\hline 2006 & 3 & 3,6 \\
\hline total & 84 & 100 \\
\hline & & \\
\hline
\end{tabular}

Fonte: Dados de 1989 a 2006. Construído a partir das informações disponíveis na Câmara dos Deputados, Senado Federal, Presidência da República e Ministério da Justiça do Brasil.

A análise da legislação aprovada em segurança pública e justiça criminal por ano aponta que, de 1989 a 2006, o maior número de aprovações ocorreu nos primeiros anos em que governos diferentes assumiram o poder. Após o período de estabilização democrática, das reformas políticas e flexibilização da economia (1988 a 1994), vê-se que no primeiro ano do governo FHC (1995) foram aprovadas 11 leis de toda legislação na área pesquisada. No segundo ano do governo FHC (1996), foram sancionadas oito leis. Esses números são próximos ao número de leis aprovadas no primeiro ano do governo Lula (2003), no qual foram aprovadas 10 leis. 
A hipótese é que os primeiros anos das legislaturas são os de maior número de propostas aprovadas na área temática pesquisada. Esses resultados, ou seja, o maior número de aprovações dependem também do partido majoritário que esteve no poder, já que o processo legislativo é essencialmente favorável ao partido majoritário que têm seus projetos aprovados mais facilmente de acordo com os seus interesses.

Aqui, o parlamentar ou o Executivo age não apenas para satisfazer as aspirações ou desejos da opinião pública ou ter "ganhos coletivos", mas porque em alguma matéria, mesmo não sendo de reivindicação do eleitorado, pode tornar-se importante como plataforma de governo em época de eleições. Isso implica que o parlamentar ou a sanção do Executivo “(...) age não só para satisfazer as aspirações imediatas dos eleitores, mas calcula conforme as possibilidades futuras de sua decisão afetar a avaliação sobre sua atuação" (Lemos, 2001, p. 575).

Claro que agregar vontades coletivas em uma determinada política pública específica não é algo simples, mas de extrema complexidade. Essa influência, no entanto, certamente ocorre ainda que não sempre de forma direta. Pensar a relação opinião pública-política é pensá-la de forma complexa, difusa e não linear em sociedades democráticas. Essa relação certamente ocorre, mas envolve uma multiplicidade de atores (parlamentares, meios de comunicação de massa, grupos organizados da sociedade civil, partidos), ideias, interesses e instituições que podem ou não atender as demandas da sociedade civil de cada país, ou, melhor dizendo, ainda, dentro de cada país em um dado momento específico e de acordo com a reivindicação ${ }^{7}$.

Lemos (2001) analisou a distribuição de benefícios sociais no período 1988-1994 do Congresso Nacional através das propostas legislativas apresentadas nas áreas de saúde e educação e se essas propostas pretenderam distribuir benefícios agregados (a grupos e indivíduos) ou difusos (a toda sociedade). Suas conclusões apontam que as escolhas dos parlamentares brasileiros nas áreas de saúde e educação concentraram-se também nos primeiros anos das legislaturas - 1989 e 1991 (em 1989 foram 238 propostas apresentadas contra 110 em 1990; em 1991 foram 177 contra 47 propostas apresentadas em 1994).

Bourdieu (1997) e Champagne (1996), por exemplo, criticam a noção de opinião pública coerente e racional, pois para eles tal opinião é manipulada pelos meios de comunicação de massa e pelo campo jornalístico, além de ser um bem de consumo e, portanto, consumido desigualmente entre as classes e grupos sociais. 
Por se tratarem de temas com ampla repercussão na opinião pública as políticas de segurança pública e justiça criminal tornam-se importantes naquilo que Habermas (2003) entende como "publicidade" através do caráter público de debates judiciais como estes.

\section{Legislação aprovada por mandatos presidenciais}

Tabela 2 - Legislação em segurança pública e justiça criminal aprovada mandatos presidenciais

\begin{tabular}{c|c|c}
\hline presidente & frequência & $\%$ \\
\hline Sarney & 4 & 4,8 \\
\hline Collor & 5 & 6 \\
\hline Itamar Franco & 8 & 9,5 \\
\hline FHC1 & 31 & 36,9 \\
\hline FHC2 & 17 & 20,2 \\
\hline Lula & 19 & 22,6 \\
\hline Total & 84 & 100 \\
\hline
\end{tabular}

Fonte: Dados de 1989 a 2006. Construído a partir das informações disponíveis na Câmara dos Deputados, Senado Federal, Presidência da República e Ministério da Justiça do Brasil.

Entre 1994 e 1997, a bancada do PSDB tornou-se a segunda maior da Câmara Federal num aumento de mais de 50\% (63 cadeiras para 97). No Senado, o aumento representou $40 \%$ (de 10 cadeiras para 14 cadeiras). Se pensarmos nos partidos da coalizão, o antigo PFL tinha 105 deputados e o PPB teve um acréscimo de 50\% em suas cadeiras - 52 para 79 deputados (Meneguello, 1998, p. 148).

Pensar na influência partidária da coalizão nas políticas de um governo é pensar que os governos FHC e Lula foram capazes de exercer uma influência importante sobre a organização do sistema partidário no que diz respeito à coalizão governamental, o que pode ter refletido no número de propostas sancionadas em segurança pública e justiça criminal: 31 propostas no primeiro mandato de FHC; 17 propostas no segundo mandato, totalizando 48 leis em oito anos de governo num total de $57,1 \%$ de leis sancionadas na área pesquisada. O governo Lula teve 19 propostas aprovadas no primeiro mandato.

Tal predominância nos primeiros anos de governo FHC e Lula, juntamente com o menor número de leis aprovadas nos anos eleitorais, pode ocorrer por pelo menos três fatores, de acordo com Lemos (2001): i) para colher os possí- 
veis benefícios das leis aprovadas em anos eleitorais é preciso que muitas das leis sejam sancionadas antes das eleições, para que tanto o Executivo como os parlamentares possam construir sua imagem de grande atividade parlamentar; ii) anos eleitorais demandam tempo de campanha e energia, o que pode diminuir ou mesmo obstruir a agenda, exigindo menos compromissos com a atividade parlamentar. Nos debates eleitorais também seria necessário ter um acúmulo anterior de atividade legislativa demonstrando seu desempenho como legislador; iii) os primeiros anos de mandato representam uma oportunidade de mostrar aos eleitores suas posições e cumprir promessas de campanha.

Cabe ressaltar que a constatação de que a atividade legislativa não se concentrou aqui nos anos eleitorais não significa dizer que ela não pode ser utilizada com fins de reeleição. Isso porque a maior atividade parlamentar nos anos subsequentes às eleições também pode ser utilizada como plataforma de governo.

\section{Legislação aprovada por partido}

Em relação às iniciativas dos deputados e senadores, os dados referem-se somente aos projetos de leis com origem na Câmara dos Deputados e no Senado Federal - o que totalizou 40 iniciativas que são oriundas especificamente do Congresso Nacional, de acordo com a tabela a seguir:

Tabela 3 - Legislação em segurança pública e justiça criminal aprovada por partidos

\begin{tabular}{c|c|c}
\hline partido do autor(a) & frequência & $\%$ \\
\hline PDT & 2 & 5 \\
\hline PT & 8 & 20 \\
\hline PTB & 2 & 5 \\
\hline PMDB & 10 & 25 \\
\hline PL & 2 & 5 \\
\hline PFL & 4 & 10 \\
\hline PSB & 4 & 10 \\
\hline PSDB & 5 & 12,5 \\
\hline PC do B & 1 & 2,5 \\
\hline PPB & 2 & 5 \\
\hline Total & 40 & 100 \\
\hline Missing & 44 & \\
\hline Total & 84 & \\
\hline & & \\
\hline
\end{tabular}

Fonte: Dados de 1989 a 2006. Construído a partir das informações disponíveis na Câmara dos Deputados, Senado Federal, Presidência da República e Ministério da Justiça do Brasil. 
Tabela 4 - Legislação aprovada em segurança pública e justiça criminal: tipo de punição por partido

\begin{tabular}{|c|c|c|c|c|c|c|c|}
\hline \multicolumn{8}{|c|}{ tipo de punição } \\
\hline \multicolumn{2}{|c|}{ partido do autor } & leis mais & ampliação & criminalização de & leis mistas & outras & total \\
\hline \multirow{2}{*}{ PDT } & frequência & 1 & 0 & 1 & 0 & 0 & 2 \\
\hline & $\%$ & $2,5 \%$ &, $0 \%$ & $2,5 \%$ &, $0 \%$ &, $0 \%$ & $5,0 \%$ \\
\hline \multirow{2}{*}{ PT } & frequência & 1 & 1 & 4 & 1 & 1 & 8 \\
\hline & $\%$ & $2,5 \%$ & $2,5 \%$ & $10,0 \%$ & $2,5 \%$ & $2,5 \%$ & $20,0 \%$ \\
\hline \multirow{2}{*}{ PTB } & frequência & 0 & 1 & 1 & 0 & 0 & 2 \\
\hline & $\%$ &, $0 \%$ & $2,5 \%$ & $2,5 \%$ & $0 \%$ &, $0 \%$ & $5,0 \%$ \\
\hline \multirow{2}{*}{ PMDB } & frequência & 3 & 5 & 1 & 0 & 1 & 10 \\
\hline & $\%$ & $7,5 \%$ & $12,5 \%$ & $2,5 \%$ &, $0 \%$ & $2,5 \%$ & $25,0 \%$ \\
\hline \multirow[t]{2}{*}{$\mathrm{PL}$} & frequência & 0 & 1 & 0 & 0 & 1 & 2 \\
\hline & $\%$ &, $0 \%$ & $2,5 \%$ &, $0 \%$ &, $0 \%$ & $2,5 \%$ & $5,0 \%$ \\
\hline \multirow[t]{2}{*}{ PFL } & Frequência & 2 & 1 & 1 & 0 & 0 & 4 \\
\hline & $\%$ & $5,0 \%$ & $2,5 \%$ & $2,5 \%$ &, $0 \%$ &, $0 \%$ & $10,0 \%$ \\
\hline \multirow{2}{*}{ PSB } & frequência & 0 & 2 & 1 & 0 & 1 & 4 \\
\hline & $\%$ &, $0 \%$ & $5,0 \%$ & $2,5 \%$ &, $0 \%$ & $2,5 \%$ & $10,0 \%$ \\
\hline \multirow{2}{*}{ PSDB } & frequência & 1 & 1 & 0 & 2 & 1 & 5 \\
\hline & $\%$ & $2,5 \%$ & $2,5 \%$ &, $0 \%$ & $5,0 \%$ & $2,5 \%$ & $12,5 \%$ \\
\hline \multirow{2}{*}{$\mathrm{PCdoB}$} & frequência & 0 & 0 & 0 & 0 & 1 & 1 \\
\hline & $\%$ &, $0 \%$ &, $0 \%$ &, $0 \%$ &, $0 \%$ & $2,5 \%$ & $2,5 \%$ \\
\hline \multirow{2}{*}{ PPB } & frequência & 1 & 1 & 0 & 0 & 0 & 2 \\
\hline & $\%$ & $2,5 \%$ & $2,5 \%$ &, $0 \%$ &, $0 \%$ &, $0 \%$ & $5,0 \%$ \\
\hline \multirow{2}{*}{ total } & frequência & 9 & 13 & 9 & 3 & 6 & 40 \\
\hline & $\%$ & $22,5 \%$ & $32,5 \%$ & $22,5 \%$ & $7,5 \%$ & $15,0 \%$ & $100,0 \%$ \\
\hline
\end{tabular}

Fonte: Dados de 1989 a 2006. Construído a partir das informações disponíveis na Câmara dos Deputados, Senado Federal, Presidência da República e Ministério da Justiça do Brasil.

Os partidos tradicionalmente localizados no espectro político-partidário de esquerda ou centro-esquerda propuseram um total de 15 leis na temática da segurança pública e da justiça criminal: uma lei do PCdoB, duas de autoria do PDT, quatro do PSB e oito do PT. Tal classificação do espectro político-partidário foi baseada na análise de Leôncio Rodrigues $(2002)^{8}$.

8 Leôncio (2002, p. 14) analisa a relação entre os meios sócio-ocupacionais de recrutamento partidário e as orientações político-programáticas dos partidos na escala ideológica direita-centro-esquerda. No entanto, segundo o próprio autor, os termos direita-centro e esquerda são utilizados de forma convencional:"(...) de acordo com o senso comum, tal como são entendidas habitualmente pela mídia, pela opinião pública e pela maioria dos cientistas políticos, brasileiros e brasilianistas, que estudam o nosso sistema partidário." 
As leis aprovadas dos parlamentares do PSB, por exemplo, correspondem a quatro leis. Destas, duas visaram à ampliação de direitos: a Lei $\mathrm{n}^{\circ} 8.653$, de 1993, "proibiu o transporte de presos em compartimentos de proporções reduzidas, com ventilação deficiente ou ausência de luminosidade"; a Lei n 9.520, de 1997, revogou o art. 35, que estabelecia: "A mulher casada não poderá exercer o direito de queixa sem consentimento do marido, salvo quando estiver dele separada ou quando a queixa for contra ele. Parágrafo único. Se o marido recusar o consentimento, o juiz poderá supri-lo.”

O Partido dos Trabalhadores apresentou oito projetos que resultaram em leis. Olhando a totalidade dos projetos que deram origem às normas sancionadas vê-se que quatro das oito leis oriundas do partido dos trabalhadores propuseram a criminalização de novas condutas: Lei $\mathrm{n}^{\circ}$ 9.778, de 1998, que definiu como crimes as condutas que favorecem ou configuram trabalho forçado e escravo; Lei ${ }^{\circ} 10.224$, de 2001 , que criou o crime de assédio sexual; Lei ${ }^{\circ} 10.886$, de 2004, que estabeleceu o crime de violência doméstica; Lei $n^{\circ} 11.106$, de 2005, que tipificou os crimes de atentado ao pudor, tráfico internacional de pessoas e tráfico interno de pessoas.

Já a Lei n 9.046, de 1995, foi oriunda de projeto de lei da Deputada Benedita da Silva (PT-RJ) e visou ampliar os direitos das mulheres detentas, pois estabeleceu que os estabelecimentos penais destinados a mulheres passassem a ser dotados de berçário e instalação destinada a estágio de estudantes universitários.

Por outro lado, a Lei n 9.459, de 1997, proposta do então Deputado Paulo Paim (PT-RS) ${ }^{9}$, denomina-se como uma proposta de lei mista. Isso porque a proposta aumentou e diminuiu as penas para os crimes de preconceito e discriminação racial. $\mathrm{O}$ art. 20 diz: "Praticar, induzir ou incitar, pelos meios de comunicação social ou por publicação de qualquer natureza, a discriminação ou preconceito de raça, por religião, etnia ou procedência nacional estabelecia antes pena de reclusão de dois a cinco anos" (grifos nossos). Com a nova proposta do deputado Paim o artigo 20 passou a definir que: "Praticar, induzir ou incitar a discriminação ou preconceito de raça, cor, etnia,

O atual senador Paulo Paim possui também propostas neocriminalizadoras, por exemplo, o Projeto de Lei do Senado n 107, de 2003, que visa alterar o Estatuto da Criança e do Adolescente para criar uma nova medida que amplie a punição no caso de crianças e adolescentes envolvidos em casos de tráfico de drogas, envolvimento com crime organizado ou crime mediante grave ameaça e violência à pessoa. Atualmente, o projeto está tramitando no Senado Federal. O projeto vai de encontro ao princípio da brevidade da medida privativa de liberdade do ECA. 
religião ou procedência nacional. Pena: reclusão de um a três anos e multa" (grifos nossos).

Já o art. 140, da mesma lei, antes estabelecia que: "Injuriar alguém, ofendendo-lhe a dignidade ou o decoro: Pena: detenção, de um a seis meses, ou multa" (grifos nossos). Com a nova lei proposta pelo deputado Paim o artigo $140, £ 3^{\circ}$, dispôs que: "Se a injúria consiste na utilização de elementos referentes à raça, cor, etnia, religião ou origem: pena: reclusão de um a três anos e multa" (grifos nossos).

Outra iniciativa de parlamentar do PT foi a Lei ${ }^{\circ}$ 9.807, de 1999, que estabeleceu normas para a organização e manutenção de programas especiais de proteção a vítimas e testemunhas ameaçadas instituindo o Programa Federal de Assistência a Vítimas e a Testemunhas Ameaçadas. Classifiquei essa lei de arranjo institucional alternativo.

Já os partidos de centro aprovaram 15 leis, sendo que o PSDB aprovou cinco leis e o PMDB, 10.

O PSDB apresentou uma lei que visou à ampliação de direitos: a Lei no 9.521, de 1997, "descaracterizou como contravenção penal a exploração da credulidade pública mediante sortilégios, predição do futuro, explicação de sonho ou praticas congêneres". Outras duas leis recrudesceram as penas em relação ao anterior, por exemplo, a Lei no 9.281 , de $1996^{10}$, e a Lei n ${ }^{\circ} 10.409$, de $2002^{11}$. Ainda, a iniciativa de concessão do chamado foro privilegiado (Lei no 10.628, de 2002) à ex-autoridade de cargo público foi proposta de parlamentar do $\mathrm{PSDB}^{12}$. Por último é de inciativa desse partido a Lei $\mathrm{n}^{\circ}$ 10.826, de 2003, que instituiu o SINARM ${ }^{13}$.

Já o PMDB, partido que detém o maior percentual de leis aprovadas em segurança pública e justiça criminal (10 leis), teve a iniciativa em todos os "tipos" de punição. Na área de defesa e efetivação de direitos o partido foi autor do projeto de lei que deu origem ao Estatuto da Criança e Adolescente ${ }^{14}$

\footnotetext{
10 Aumenta a pena de reclusão de seis a 10 anos para os crimes de estupro e ato libidinoso, se a ofendida é menor de 14 anos, a violência não é presumida, se o ofendido é menor de 14 anos.

11 Dispõe sobre a prevenção, o tratamento, a fiscalização, o controle e a repressão à produção, ao uso e ao tráfico ilícitos de produtos, substâncias ou drogas ilícitas que causem dependência física ou psíquica, assim elencados pelo Ministério da Saúde.

12 Deputado Bonifácio de Andrada PSDB-MG.

13 Sistema Nacional de Armas (SINARM) - Dispõe sobre registro, posse e comercialização de armas de fogo e munição.

14 Senador Ronan Tito (PMDB-MG).
} 
e do dispositivo que criou os chamados Juizados Especiais Criminais ${ }^{15}$ (Lei 9.099 de 1995). Ao mesmo tempo, parlamentares do PMDB apresentaram projetos de leis que expressam o recrudescimento penal (Garland, 2001) em leis que visaram restringir mais ainda os direitos dos detentos. Por exemplo, as Leis $n^{\circ}$ 8.701, de 1993, que considera feitas as intimações pela simples publicação dos atos no órgão oficial, ou a Lei no 9.034, de 1995, de iniciativa do Deputado Michel Temer, que dispões sobre os meios de prevenção e repressão as ações praticadas por "organizações criminosas".

Quanto aos partidos de direita: PL, PP (ex-PPB), DEM (ex-PFL) e PTB totalizam 10 leis propostas. Aqui também não é possível traçar uma relação unicausal de "afinidade eletiva" entre direita e punição, embora a maioria dos projetos mais punitivos tenham sido oriundos desses parlamentares. A Lei $n^{\circ} 10.713$, de 2003, por exemplo, tornou direito do preso o atestado de pena com o tempo determinado a cumprir, a ser emitido anualmente pelo juiz da execução penal. A proposta foi do Deputado Ricardo Barros (PP-RR), por exemplo. A Lei n 7.871, de 1989, que deu início à Defensoria Pública foi proposta pelo Deputado Fábio Raunheitti (PTB-RJ).

No entanto, os partidos de centro e direita apresentaram algumas das leis mais punitivas em segurança pública e justiça criminal (principalmente iniciativas das Leis de Crimes Hediondos). Por exemplo, a Lei de Crimes Hediondos $n^{\circ} 8.072$, de $1990^{16}$, de Origem do Senador Odacir Soares (PFL-RO), proposta através do Projeto de Lei do Senado (PLS) nº 50, de 1990. Para se ter uma ideia da rapidez com que tal lei foi sancionada, o tempo de tramitação entre apresentação do projeto de lei e a sanção da Lei de Crimes

\footnotetext{
Deputado Michel Temer (PMDB-SP).

${ }^{16}$ A Lei no 8.072, de 1990, estabeleceu os crimes hediondos. Em seguida, foram-lhe acrescentadas novas tipificações através das Leis nos 8.930, de 1994; 9.695, de 1998; e 9.677, de 1998. Por meio dessas emendas, são considerados em nossa legislação os seguintes crimes hediondos: i) atentado violento ao pudor; ii) envenenamento de água potável ou de substância alimentícia ou medicinal, qualificado pela morte; iii) epidemia com resultado de morte; iv) extorsão qualificada pela morte; v) extorsão mediante sequestro; vi) falsificação, corrupção, adulteração ou alteração de produto destinado a fins terapêuticos ou medicinais; vii) homicídio simples (chamado no Congresso de "Caso Daniela Perez"); viii) genocídio. Essas condutas, assemelhadas à camada "hediondez", receberam qualitativamente e quantitativamente as mesmas punições da lei de crimes hediondos. Lembro que a categoria "crimes hediondos"já havia sido incluída no inciso XLIII do art. $5^{\circ}$ da Constituição Federal, que instituiu os crimes inafiançáveis e insuscetíveis de graça ou anistia, a prática da tortura, o tráfico ilícito de entorpecentes e drogas afins, o terrorismo e os definidos como crimes hediondos, por ele respondendo os mandantes, os executores e os que, podendo evitá-los, se omitirem.
} 
Hediondos foi de 68 dias $^{17}$. Também, a Lei no 9.677 , de 1998, que inclui a classificação dos delitos considerados hediondos os crimes contra a saúde pública, de autoria do Deputado Benedito Domingos (PPB-DF), tramitou 118 dias até a sanção presidencial.

Sobre esse aspecto, cito rapidamente a reflexão de Pierucci (1999) sobre essa (nova) direita. Apesar de no Brasil poucos políticos se afirmarem como tal, como vimos, essa direita possui uma pluralidade de temas que não guarda limites claros, mas que elege a defesa da instituição familiar como prioridade de qualquer projeto de sociedade. Direita entendida aqui, portanto, não apenas como conservação política, mas acima de tudo como uma proposta de sociabilidade que visa à conservação social, diferente da proposta da "modernidade ilustrada", pois combina práticas e discursos baseados em preconceitos: "Noutras palavras, mais do que no campo político stricto sensu, as direitas se constituem e se difundem no campo metapolítico das relações sociais quotidianas, dos modos e estilos de vida e da luta cultural" (Pierucci, 1999, p. 18).

Citei aqui somente alguns exemplos de normas propostas pelos partidos. Como pode ser visto, diferentes normas foram propostas por diferentes parlamentares dos diversos partidos presentes no Congresso Nacional. De um modo geral, vimos que cada partido (principalmente os de maior número de propostas) teve proposições apresentadas na maioria dos diversos "tipos de punição".

Para Bourdieu (1998) o uso da linguagem depende da posição social do locutor que comanda o acesso à língua da instituição - a linguagem legítima - pois quem enuncia as palavras "está autorizado", ou seja, concentra o capital simbólico do grupo que lhe conferiu o poder. A potência e a legitimidade do discurso são proporcionais à autoridade de quem o enuncia e de quem está autorizado a enunciar. O poder das palavras reside, desse modo, na objetivação e oficialização feita pela nomeação pública, que tem por efeito principal extrair a particularidade do grupo que deve ser institucionalizado quando o linguajar inominável torna-se falado publicamente.

A oficialização, por meio dos parlamentares, encontra-se realizada na manifestação na qual o grupo ignorado (e reprimido) torna-se visível a todos os outros grupos, como também a si mesmo, afirmando sua existência

17 Segundo Mendonça (2006) a Lei no 8.072, de 1990, foi aprovada em um contexto de pressões da opinião pública, mediante a onda de sequestros a partir de 1989 em São Paulo e, sobretudo, no Rio de Janeiro com o sequestro do empresário Roberto Medina. 
e sua "pretensão" a ser institucionalizado. Portanto, é fundamental para entendermos os mecanismos do discurso e da institucionalização (da criminalização) compreender que o mundo social é representação e vontade e, nesse sentido, existir socialmente também é ser percebido fundamentalmente como "distinto". Desse modo, a instituição é um ato de magia social capaz de criar a diferença ou, ainda, como é mais frequentemente realizado, de explorar as diferenças preexistentes. É um "delírio bem fundado", que institui uma identidade que pode ser tanto um título de nobreza (foro privilegiado) quanto um estigma (hediondo), impondo um nome e uma essência social. Estas fazem simultânea e supostamente ver o que alguém supostamente seria e como deveria se comportar em função de tal ou qual identidade e conduta.

\section{Legislação aprovada por estado e região do proponente de projeto de lei no Congresso Nacional \\ Estados e regiões do Brasil}

Tabela 5 - Legislação aprovada por segurança pública e justiça criminal por estado e região

\begin{tabular}{c|c|c}
\hline estado & frequência & $\%$ \\
\hline Rondônia & 1 & 2,5 \\
\hline Acre & 2 & 5 \\
\hline Roraima & 1 & 2,5 \\
\hline Pará & 2 & 5 \\
\hline Amapá & 2 & 5 \\
\hline Pernambuco & 2 & 5 \\
\hline Minas Gerais & 6 & 15 \\
\hline Espírito Santo & 2 & 5 \\
\hline Rio de Janeiro & 6 & 15 \\
\hline São Paulo & 10 & 25 \\
\hline Rio Grande do Sul & 2 & 5 \\
\hline Mato Grosso & 1 & 2,5 \\
\hline Goiás & 1 & 2,5 \\
\hline Distrito Federal & 2 & 5 \\
\hline total & 40 & 100 \\
\hline valores omissos & 44 & \\
\hline total & 84 & \\
\hline
\end{tabular}


Tabela 6 - Legislação aprovada por segurança pública e justiça criminal por estado e região

\begin{tabular}{c|c|c}
\hline regiões do país & frequência & $\%$ \\
\hline Norte & 8 & 20 \\
\hline Nordeste & 2 & 5 \\
\hline Sudeste & 24 & 60 \\
\hline Sul & 2 & 5 \\
\hline Centro 0este & 4 & 10 \\
\hline total & 40 & 100 \\
\hline valores omissos & 44 & \\
\hline total & 84 & \\
\hline
\end{tabular}

Fonte: Dados de 1989 a 2006. Construído a partir das informações disponíveis na Câmara dos Deputados, Senado Federal, Presidência da República e Ministério da Justiça do Brasil.

Os dados referentes aos estados e regiões indicam que São Paulo, Rio de Janeiro, Minas Gerais e Espírito Santo representam 60\% da produção legislativa na área de segurança pública e justiça criminal no período de 1989 a 2006. Nesse período a região Sudeste possuía alguns dos maiores índices de criminalidade, principalmente, no que se refere à violência letal no Brasil (capitais e estados), e também abrigava algumas das regiões mais urbanizadas (Cano, 2006) do país, como as capitais e regiões metropolitanas de Rio de Janeiro, São Paulo, Belo Horizonte e Vitória ${ }^{18}$. O Mapa da violência dos municípios brasileiros (Waiselfisz, 2008), por exemplo, quantificou os 200 municípios com maior número de mortes por armas de fogo. Os dados referentes ao nosso período estudado indicavam que, até o ano de 2006, o Rio de Janeiro teve 2.235 óbitos; São Paulo, 2.151 óbitos; Recife, 1.198 óbitos; e Belo Horizonte, 1.038 óbitos. Na proporção por 100 mil habitantes, temos taxas de 37,1 por $100 \mathrm{mil} / \mathrm{hab}$ para a cidade do Rio de Janeiro; 20,0 para São Paulo; 79,2 para Recife; 43,7 para Belo Horizonte; e 75,0 para Vitória ${ }^{19}$.

\footnotetext{
18 A estimativa de número de homicídios para o estado do Rio de Janeiro em 2002, com base nas certidões de óbito processadas pelo Ministério da Saúde, é de 8.930 vítimas residentes no estado em uma taxa de 60 homicídios por 100 mil habitantes (Cano, 2006). Os dados das taxas de homicídios da população total por estados, do "Mapa da violência IV", apontam que, de 1993 a 2002, o estado do Rio de Janeiro ocupava o primeiro lugar, com 56,5 em 100 mil habitantes; em segundo, encontrava-se Pernambuco, com 54,5; em terceiro, Espírito Santo, com 51,2; em quarto, Rondônia, com 42,3; e em quinto, São Paulo, com 38,0. Minas ocupou o $21^{\circ}$ lugar, com 16,2. Quando as taxas são isoladas de acordo com as capitais, tínhamos o seguinte ordenamento: em primeiro lugar, Recife, com 90,5 por 100 mil; em segundo, Vitória, com 80,2; em quarto, Rio de Janeiro, com 62,8; e em sétimo, Belo Horizonte, com 52,6 (Waiselfisz, 2004).

19 O Mapa da violência de 2012 (Waiselfisz, 2011) constatou uma mudança nos homicídios das regiões
} 
Entretanto, acrescentamos a essa hipótese o fato de que nesses locais, principalmente nas capitais do Rio de Janeiro e São Paulo, a mídia tem exercido a função de "publicidade" de crimes de grande repercussão pública como instrumento importante para "despertar" a opinião pública para os crimes ocorridos nessas capitais e estado ${ }^{20}$ reivindicando, desse modo, mais punição por meios dos meios de comunicação de massa e refletindo no Parlamento, conforme minha análise anterior sobre as propostas de redução da idade penal (Campos, 2009).

Por exemplo, o projeto de lei que tornou hediondo o crime de homicídio simples no Brasil - Projeto de Lei no 4.146 de 1993 - fez parte das proposições que o próprio Legislativo denominou "Iniciativa Daniela Perez"21. O projeto deu origem à Lei no 8.930 , de 1994, que deu nova redação ao art. $1^{\circ}$ da Lei $\mathrm{n}^{\circ}$ 8.072, de 25 de julho de 1990, que dispõe sobre os crimes hediondos, nos termos do art. $5^{\circ}$, inciso XLIII, da Constituição Federal.

Outro exemplo é a lei no 11.343, de 2006 (Nova Lei de Drogas), que começou a tramitar no Legislativo no início dos anos 2000. O Projeto de Lei do Senado no 115, de 2002, foi de autoria da Comissão Mista de Segurança Pública - "Grupo de Trabalho da Subcomissão Crime Organizado, Narcotráfico e Lavagem De Dinheiro (Grupo 3)". O projeto foi apresentado no dia 7 de maio de 2002 e é de iniciativa do Senado Federal. O Relator inicialmente designado foi o Deputado Moroni Torgan (DEM/CE). Como presidente dessa comissão, na época, foi designado o Senador Iris Rezende (PMDB/GO) e, como vice-presidente, o Senador Artur da Távola (PSDB/RJ).

A Comissão Mista de Segurança Pública foi criada pelo Legislativo brasileiro em 2002. O contexto histórico-político de sua criação refere-se àquilo que a grande mídia, senadores e deputados nomearam na época como "onda

metropolitanas (RMs). Hoje as maiores taxas de homicídios por 100 mil habitantes estão nas RM de Maceió, depois Belém e, em seguida, João Pessoa. Vitória é a quarta nas taxas de homicídios. São Paulo hoje ocupa a 29a posição; Rio de Janeiro, a 22a; e Belo Horizonte, a 15a posição.

20 Não entramos aqui na questão da sub-representação ou sobre-representação dos Estados no Congresso Nacional. Sobre o tema, ver os importantes trabalhos de Nicolau $(1997,1991)$ e Santos $(1997,1998)$.

${ }^{21}$ A morte da atriz Daniella Perez foi um dos crimes de maior repercussão pública e midiática. Filha de uma diretora de novela da Rede Globo de televisão, o crime, ocorrido em 28 de dezembro de 1992, recebeu ampla cobertura da imprensa e forte pressão no Congresso Nacional. Daniella, que à época fazia uma telenovela de grande audiência nacional chamada De corpo e alma, foi assassinada por Guilherme de Pádua, que fazia par romântico com a vítima na trama, e por Paula Thomaz, esposa de Guilherme. O corpo da atriz foi encontrado em uma região de floresta na Barra da Tijuca, no Rio de Janeiro. 
de sequestros" 22 . De modo sucinto, pode-se dizer que foi um contexto histórico de grande repercussão pública dada a alguns sequestros que ocorreram na capital paulista, depois na cidade de Campinas (que culminou na prisão de $A$ ndinho $\left.{ }^{23}\right)$ e na região de São José dos Campos.

A justificativa central ${ }^{24}$ dada para a implementação dessa Comissão em 2002 foi a seguinte:

A criação da Comissão Parlamentar Mista Especial de Segurança Pública deveu-se a motivos que a todos ainda ressoam bem vibrantes. Nasceu no bojo da escalada da violência no início deste janeiro, mais especificamente por ocasião do desate de ondas intermináveis de sequestros. O Congresso Nacional viu-se, então, na obrigação de mobilizar todas as forças partidárias em prol da superação de tão grave problema. Composta por vinte Senadores e vinte Deputados (e igual número de suplentes), a Comissão prontificou-se, num prazo exíguo de sessenta dias, a apresentar em textos consolidados não somente projetos de lei, mas também propostas de emenda à Constituição (...). Modificações substanciais no Código de Processo Penal brasileiro são adotadas com o propósito de reduzir tanto o número de recursos quanto a duração dos processos criminais, tentando extinguir de vez o problema da morosidade da Justiça. Além disso, a Comissão determina punições mais rigorosas para crimes de grande potencial ofensivo, tráfico de armas, narcotráfico e o crime organizado. Nessas condições, a punição para o crime de sequestro será agravada, bem como os crimes de terrorismo e de lavagem de dinheiro serão finalmente enquadrados na legislação penal. Novas tipificações criminais foram reconhecidas, tais como sequestro-relâmpago (extorsão mediante privação de liberdade), extorsão mediante sequestro por meio de transporte coletivo, clonagem de cartão e celular, pedofilia na internet e, por fim, roubo e receptação de carga (grifos nossos).

\footnotetext{
${ }^{22}$ Há um resumo interessante sobre o aumento da cobertura midiática do período, no site do Observatório de Segurança Pública (OSP/UNESP) (s.d.). Citando-o: "Grande parte das matérias procura salientar o aumento considerável dos casos de sequestros. Um caderno especial procurou ouvir as vítimas do sequestro e identificar o perfil do agressor. Sequestros relâmpagos ou roubos qualificados? Em 1999, o crime de sequestro recebeu uma adjetivação nova: sequestro relâmpago. No caderno Arquitetura da Violência, página 8, no dia 24 de novembro de 1999, a matéria“Um morador de SP é vítima de sequestro relâmpago a cada 5 horas" informa que até o mês de julho ocorreram 158 sequestros relâmpagos.

23 Wanderson Nilton Paula Lima, o Andinho, possui ao menos 17 condenações por sequestros, homicídios, roubos e tráfico de drogas e também 31 mandados de prisão preventiva. Ele também foi acusado e denunciado pelo Ministério Público à Justiça pelo assassinato do prefeito de Campinas Antonio da Costa Santos, o Toninho do PT, em 2001. Ele sempre negou participação no crime.

24 "Introdução" do Relatório de Criação da Comissão. Brasília, 16 de abril de 2002, Deputado Moroni Torgan (Relator).
} 
Esses são dois exemplos de influência da mídia que podem ser demonstrados por meio de material histórico do Legislativo quando da tramitação destas duas leis: Lei $n^{\circ} 8.930$, de 1994, e Lei $n^{\circ} 11.343$, de 2006. Segundo Miguel (2002) esse tipo de análise é importante para a compreensão de que há uma relação entre meios de comunicação e política que seja capaz de apreender a interconexão entre as duas esferas e a centralidade crescente da mídia no jogo político atual. Claro que se trata de campos distintos (opinião pública e política ${ }^{25}$ ), e não fazemos aqui uma análise mecânica entre esses dois campos, mas há uma influência dos meios de comunicação que é particularmente sensível num dado momento crucial do jogo político e na definição de uma agenda num contexto específico.

Através dos meios de comunicação ocorre a influência da "opinião pública”, ou seja, alguns indivíduos (no caso, os parlamentares) organizam suas percepções (seus esquemas interpretativos) sobre uma determinada temática, mediante influência dada pela repercussão pública de alguns crimes, e assim reivindicam em seguida determinada política pública e punição.

Tabela 7 - Casa iniciadora da tramitação do projeto de lei que originou a lei

\begin{tabular}{c|c|c}
\hline casa propositora & frequência & $\%$ \\
\hline Câmara dos Deputados & 33 & 39,3 \\
\hline Senado Federal & 13 & 15,5 \\
\hline Executivo & 36 & 42,9 \\
\hline Congresso Nacional & 1 & 1,2 \\
\hline Judiciário & 1 & 1,2 \\
\hline total & 84 & 100 \\
\hline
\end{tabular}

Fonte: Dados de 1989 a 2006. Construído a partir das informações disponíveis na Câmara dos Deputados, Senado Federal, Presidência da República e Ministério da Justiça do Brasil.

Em relação aos projetos que deram origem às normas promulgadas estudadas, temos um equilíbrio quanto às propostas de iniciativa na Câmara dos Deputados e do Executivo: 42,9\% da legislação em segurança pública e

\footnotetext{
25 Nessa perspectiva, Bourdieu (1997) já assinalou que os dois campos, político e jornalístico, estão sob influência da sanção do mercado e do plebiscito. Possuem assim influências recíprocas: "Daí decorre que a influência do campo jornalístico reforça as tendências dos agentes comprometidos com o campo político a submeter-se à pressão das expectativas e das exigências da maioria, por vezes passionais e irrefletidas, e frequentemente constituídas como reivindicações mobilizadoras pela expressão que recebem na imprensa" (Bourdieu, 1997, p. 114-5).
} 
justiça criminal são de iniciativa do Executivo; 39,3\%, da Câmara dos Deputados; $15,5 \%$ foram projetos de lei de autoria do Senado; uma proposta foi de autoria do Congresso Nacional (projeto de CPMI Mista destinada a apurar a denúncia de Pedro Collor de Mello sobre as atividades de Paulo César Farias); e um projeto de autoria foi do Ministério Público da União (Lei $\mathrm{n}^{\circ}$ 9.035, de 1995).

Limongi e Figueiredo (1994) lembram algumas das principais diferenças entre as propostas de cada uma das casas: Judiciário e Executivo têm poder institucional de propor leis. No Legislativo o direito é individual, fruto de um processo de decisão descentralizado. Já a prerrogativa do Poder Executivo no que diz respeito à proposição legislativa é definida dessa forma pelos autores:

O Executivo tem competência exclusiva quanto a (1) matérias emergenciais - em casos de relevância e urgência pode editar medida provisória com força de lei que deve ser apreciada pelo Congresso Nacional $(\mathrm{CN})$ no prazo de trinta dias (art. 62 da constituição); e (2) matérias orçamentárias. Em ambos os casos, é importante notar, o Executivo se reporta ao $\mathrm{CN}$ reunido na forma de uma assembleia única. Nesses casos, não ocorre a apreciação separada e sequencial entre as duas casas (Limongi e Figueiredo, 1994, p. 31).

No que diz respeito ao Poder Legislativo, a Constituição de 1988 aprovou dois conjuntos distintos e contraditórios de medidas, pois os constituintes aprovaram uma série de medidas tendentes a fortalecer o Congresso, recuperando assim os poderes subtraídos do Legislativo ao longo do período militar. De outro lado, a Constituição manteve muito dos poderes legislativos dos quais o Executivo foi dotado ao longo do período autoritário, o que permitiu ao Executivo dirigir o processo legislativo durante o regime militar (Limongi e Figueiredo, 1994) ${ }^{26}$.

Os autores estudaram a produção normativa entre 1989 a 1992. Das 902 leis ordinárias promulgadas, Limongi e Figueiredo constataram que a iniciativa do Executivo correspondeu a $62,4 \%$ do total de leis aprovadas. Já a participação relativa das leis ordinárias introduzidas pelo Legislativo sobre o total da produção legislativa foi pequena: 98 em 902 leis, ou seja,

26 Sobre o tema, diz Ricci (2006, p. 48): "Se dermos uma olhada, ainda que rápida, para as performances legislativas de alguns países, observamos, em termos de leis sancionadas, uma tendência geral à prevalência das normas originadas no executivo." 
$11 \%$ do total. Restringindo-se ao universo em que o Legislativo é dotado de competência para propor leis, os autores constataram que essa participação relativa cresce, já que, o total na pesquisa dos autores foi de 267 e a participação relativa do congresso chega à marca dos $37 \%$. O regime de tramitação urgente foi pedido para a maior parte desses projetos: 53 deles ou $54 \%$ dos casos (Limongi e Figueiredo, 1994).

Dessa forma, em nossa pesquisa, ainda que o Executivo tenha um percentual menor de leis de sua iniciativa (42,9\% contra 54,8\% do Congresso Nacional), pode-se dizer que o Executivo detém um considerável poder de decisão da agenda no que diz respeito à produção legal em segurança pública e justiça criminal. Lembro ainda que no período foram aprovadas 35 leis orçamentárias nessa área, de autoria do Executivo, que foram excluídas desta análise. Assim persiste:

(...) uma diferença fundamental entre as leis introduzidas por parlamentares e aquelas que vêm do Executivo ou do Judiciário. O processo de tramitação das proposições introduzidas por parlamentares é, ao mesmo tempo, um processo coletivo de seleção. Para as propostas introduzidas pelo Executivo e pelo Judiciário, este processo de seleção é feito alhures. Assim, de acordo com sua origem, a tramitação das matérias tem caráter radicalmente diverso, pois apenas para as propostas introduzidas por parlamentares este processo é a um só tempo um processo de apreciação e de seleção (Limongi e Figueiredo, 1994 p. 27).

\section{Tipos de punição}

Em relação às categorias de classificação das leis, criei as seguintes categorias de acordo com os tipos de punição propostos:

1. Leis mais punitivas: leis que aumentaram a punição em relação à lei anterior.

2. Políticas penais alternativas: leis que reduziram punições ou ampliaram garantias e direitos dos acusados.

3. Criminalização de novas condutas: criminalização de condutas antes não criminalizáveis.

4. Leis mistas: leis que aumentam as penas em conjunto com políticas penais alternativas ou ampliam as garantias e direitos dos acusados.

5. Outras: a categoria engloba três tipos de leis, sendo: a) atuação reativa das organizações de segurança pública com novas atribuições e formas organizacionais voltadas a tornar mais visível sua presença nos espaços públicos, ampliar seus 
domínios de atuação e aumentar a eficiência de sua ação de forma reativa; b) arranjos organizacionais alternativos e preventivos intervindo nos fatores situacionais e sociais propiciadores do crime, não somente de forma reativa; iii) leis que instauram privilégios exclusivamente a um grupo.

Tabela 8 - Tipos de punição por casa propositora

\begin{tabular}{c|c|c|c|c|c|c|c}
\hline \multicolumn{2}{c|}{} & \multicolumn{7}{c}{ casa propositora } \\
\hline \multirow{2}{*}{ tipo de punição } & $\begin{array}{c}\text { Câmara dos } \\
\text { Deputados }\end{array}$ & $\begin{array}{c}\text { Senado } \\
\text { Federal }\end{array}$ & Executivo & $\begin{array}{c}\text { Congresso } \\
\text { Nacional }\end{array}$ & Judiciário & total \\
\hline \multirow{2}{*}{$\begin{array}{c}\text { leis mais } \\
\text { punitivas }\end{array}$} & frequência & 6 & 3 & 10 & 0 & 0 & 19 \\
\cline { 2 - 8 } & $\%$ & $31,6 \%$ & $15,8 \%$ & $52,6 \%$ & $0 \%$ & $0 \%$ & $100,0 \%$ \\
\hline \multirow{2}{*}{$\begin{array}{c}\text { ampliação } \\
\text { de direitos }\end{array}$} & frequência & 10 & 4 & 5 & 0 & 0 & 19 \\
\cline { 2 - 9 } & $\%$ & $52,6 \%$ & $21,1 \%$ & $26,3 \%$ & $0 \%$ & $0 \%$ & $100,0 \%$ \\
\hline $\begin{array}{c}\text { criminalização } \\
\text { de novas } \\
\text { condutas }\end{array}$ & frequência & 8 & 2 & 9 & 1 & 0 & 20 \\
\cline { 2 - 9 } leis mistas & frequência & 2 & 3 & 5 & 0 & 0 & 10 \\
\cline { 2 - 9 } & $\%$ & $20,0 \%$ & $30,0 \%$ & $50,0 \%$ & $0 \%$ & $0 \%$ & $100,0 \%$ \\
\hline \multirow{2}{*}{ outras } & frequência & 7 & 1 & 7 & 0 & 1 & 16 \\
\cline { 2 - 8 } & $\%$ & $43,8 \%$ & $6,3 \%$ & $43,8 \%$ & $0 \%$ & $6,3 \%$ & $100,0 \%$ \\
\hline total & frequência & 33 & 13 & 36 & 1 & 1 & 84 \\
\hline & $\%$ & $39,3 \%$ & $15,5 \%$ & $42,9 \%$ & $1,2 \%$ & $1,2 \%$ & $100,0 \%$ \\
\hline
\end{tabular}

Fonte: Dados de 1989 a 2006. Construído a partir das informações disponíveis na Câmara dos Deputados, Senado Federal, Presidência da República e Ministério da Justiça do Brasil.

O Executivo legislou para as leis mais punitivas $52,6 \%$ das leis aprovadas e $45 \%$ nas leis que criminalizaram novas condutas. Tal "resposta" pode ter ocorrido de forma muitas vezes a responder as demandas da opinião pública e setores organizados da sociedade civil por mais punição, atuando de forma mais reativa no caso das leis recrudescedoras e da criminalização de novas condutas do que no caso das leis que ampliam direitos, já que apenas $26,3 \%$ (cinco leis) foram de sua iniciativa. Conforme adverte Cheibub et al. (2009, p. 292): “(...) os presidentes não precisam barganhar caso a caso para aprovar suas propostas legislativas. Eles estão na posição de exigir apoio para a totalidade de sua agenda legislativa."

Ginsberg (1986) considerou esse ponto a respeito das democracias ocidentais, pois a concepção direta de um Estado democrático e forte, entendido 
apenas como reflexo da opinião pública, também permite que os governos paradoxalmente possam expandir os poderes estatais em relação aos cidadãos. Nesse sentido, o que os cidadãos pensam ser "mais controle" também pode vir a ser "uma algema": de um lado, ele expande o poder estatal; de outro, aumenta a participação dos cidadãos ${ }^{27}$.

\section{Por tipo de punição}

Por fim, apresento o resultado da legislação dividida pelo “tipo" de punição.

Tabela 9 - Tipo de punição

\begin{tabular}{c|c|c}
\hline tipo de punição & frequência & $\%$ \\
\hline leis mais punitivas & 19 & 22,6 \\
\hline ampliação de direitos & 19 & 22,6 \\
\hline criminalização de novas condutas & 20 & 23,8 \\
\hline leis mistas & 10 & 11,9 \\
\hline outras & 16 & 19,0 \\
\hline total & 84 & 100,0 \\
\hline
\end{tabular}

Fonte: Dados de 1989 a 2006. Construído a partir das informações disponíveis na Câmara dos Deputados, Senado Federal, Presidência da República e Ministério da Justiça do Brasil.

A Tabela 9 aponta para variações da política criminal brasileira, já que das 84 leis analisadas: 22,6\% representam o recrudescimento penal (leis que

\footnotetext{
${ }^{27}$ Nesse sentido, o voto aparece para o autor como o marco desse processo de influência da opinião pública nos processos governamentais. Ginsberg (1986) faz um breve histórico do voto na formação do Estado Nação. Segundo o autor, a partir do século XVIII, iniciou-se o processo de mudança na relação entre opinião pública e governo. O aspecto mais importante dessa alteração foi a construção de mecanismos de consulta popular (instituições eleitorais e representação parlamentar) e a gradual extensão do direito de voto para as classes baixas no começo do século XX, nos regimes europeus. Essas modificações colocaram para os governos a obrigação de dialogar sobre seus programas e políticas. Porém, a explicação convencional crê que a extensão do direito do voto e a representação no governo são formas unicamente resultantes das demandas populares. Para o autor, ainda que o direito de voto seja constituído por lutas dos cidadãos em determinados momentos históricos, na Europa Ocidental e nos EUA, a expansão do sufrágio, e a incorporação de demandas populares em momentos históricos específicos também fortaleceram o Estado. Um exemplo desse processo, segundo o autor, foi quando o governo americano garantiu o direito de voto aos negros na década de 1960. Outro exemplo do fortalecimento estatal pode ser a transição democrática brasileira. Para Ginsberg, esse processo pode ocorrer por quatro circunstâncias: a expansão do voto está ligada frequentemente a esforços dos grupos que estão no poder para negociar com as massas para não desafiarem o regime; um regime que seja inviável de ser suprimido pela força pode ser confrontado por uma desordem social de tal modo; ameaças externas ou a integridade territorial (guerras, por exemplo) podem expandir o sufrágio; voto popular e representação estariam associados com os esforços de centralização e expansão da autoridade nacional.
} 
restringiram direitos em relação à lei anterior); $22,6 \%$ das leis de alguma forma ampliaram os direitos dos presos; $23,8 \%$ correspondem ao percentual da legislação neocriminalizante; 11,9\% são o percentual de leis "mistas" (que numa mesma norma ampliou direitos e/ou possibilitou a aplicação de penas alternativas, ao mesmo tempo que criminalizou condutas ou/e aumentou a pena anteriormente estabelecida). Ainda, 19\% representam as leis da categoria "outras" 28 .

Os dados apontam para a ambiguidade do Executivo e do Congresso Nacional para a política de segurança brasileira pós-democratização. Entretanto, tal variedade se constitui muitas vezes através do recurso simbólico do penal, que se mostra como parte importante e integrante das políticas criminais brasileiras e das (novas) criminalizações. Não há, portanto, uma oposição entre leis mais punitivas versus leis que garantam certos direitos, mas uma coexistência entre leis formuladas com certa pretensão universalista (de expandir direitos) com uma legislação que restringe direitos (punindo mais).

Há casos em que tais princípios coexistem em uma lei aprovada, como o caso emblemático da atual lei de drogas ${ }^{29}$. Nesta, o fim da pena de prisão do usuário de drogas foi banido, pois o usuário passou a ser visto como objeto de intervenção das instituições de saúde pública. Juntamente com isso, o deputado Antônio Biscaia (PT-RJ) propôs o aumento da pena mínima para o tráfico de drogas (de três para cinco anos durante a tramitação na Câmara em 2004). Segue fragmento de um parecer ${ }^{30}$ da Comissão de Constituição, Justiça e Redação, da Câmara dos Deputados, de 2004:

O usuário ou dependente de Drogas, antes de se constituir um contraventor, deve ser visto como uma pessoa com vulnerabilidades de fundo individual e social, que não pode ser confundida com a figura do traficante. Merece, para si e para sua família, atenção à saúde e oportunidades de inserção ou reinserção social (Diário da Câmara dos Deputados, fev. 2004, p. 05402).

\footnotetext{
${ }^{28}$ A categoria foi agrupada mediante a constatação de que os percentuais são pequenos para dividir em três categorias. Quanto ao tempo médio de tramitação (em meses) das leis analisadas de acordo com o seu tipo de punição foram: Leis mais punitivas - 27,35; leis que ampliam direitos - 28,71; leis que criminalizam novas condutas - 29,79; leis mistas - 29, 26; outras - 30,63. Para uma análise na íntegra dos dispositivos classificados ver: Campos (2010).

29 Lei no 11.343, de 2006, também denominada como Sistema Nacional de Políticas Públicas sobre Drogas (SISNAD).

30 Substitutivo ao PL no 7.134, de 2002, e PL n 6.108, de 2002 - Parecer da CCJR - 12/2/2004, Relator Paulo Pimenta (PT-RS).
} 
Portanto, penso numa variedade de respostas das políticas criminais que oscilam no plano das normas entre leis mais igualitárias e ampliadoras de direitos (universalistas) e uma tendência mais punitiva e hierarquizante (muitas vezes sob o discurso da prevenção situacional). Meu objetivo foi sinalizar, em relação às teses do recrudescimento penal e do Estado Penal, que nossa legislação é perpassada também por outros modelos e concepções punitivas para além da concepção mais repressiva e que muitas vezes ocorre uma combinação de modelos punitivos em determinadas leis. A legislação corresponde às respostas governamentais e dos parlamentares com diferenciações que variam conforme o tipo de ação, o agente e a sua recepção pela opinião pública em um contexto temporal específico.

Vale lembrar que essa consideração não é estritamente nova em nossa história de formular políticas criminais. Segundo Alvarez (2010, p. 9):

Gizlene Neder, ao analisar a história das ideias políticas sobre criminalização e punição no país, indica como as elites locais buscaram legitimidade para suas propostas de modernização das instituições policiais e da justiça criminal no pensamento europeu, ora incorporando as ideias iluministas do final do século XVIII - que questionavam as execuções públicas e os suplícios, como é possível acompanhar nos debates que resultaram no Código Criminal do Império de 1830 - ora acompanhando as discussões em torno das ideias criminológicas - como no momento da elaboração do Código Penal de $1890^{31}$.

\section{Considerações finais}

O objetivo deste texto foi analisar a legislação aprovada em segurança pública e justiça criminal de 1989 a 2006. O principal resultado obtido, a partir da análise dos dados, é que a legislação nessa área temática está em disputa, ou seja, as leis aprovadas têm como característica central a coexistência de princípios diferentes de justiça: i) um mais reativo e repressivo (hierarquizante); ii) outro que visou instituir alguns direitos e garantias fundamentais dos acusados (mais universalista). Os dados apontam na direção do que Kant de Lima (1996, p. 168) já assinalou: “não há 'uma' fórmula oficial e legítima, que se considere ideal e aplicável universalmente na administração de conflitos". Apresentam-se prioritariamente normas que visam à criminalização ou ao agravamento das penas, mas também se buscou efetivar direitos e garantias dos presos.

${ }^{31}$ Ver também a análise sobre Nina Rodrigues em Alvarez (2002). 
Esses resultados colocam em xeque a ideia de que o Brasil reproduz de forma mecânica o aumento unilateral do poder de punir do Estado contemporâneo no Ocidente, principalmente dos anos 1980 em diante, com base na experiência dos EUA e de países como Inglaterra ou França. Dito de outra forma: a política de segurança pública e justiça criminal no Brasil não reproduz unicamente um "Estado Penal americano" porque existem meios de comunicação de massa, partidos políticos, movimentos sociais, presidentes, ONGs, lobbys e outros atores políticos que influenciam por meio de práticas sociais (diretas ou indiretas) esse processo.

O diálogo com a bibliografia nacional permitiu apontar a tendência de despenalização (Mendonça, 2006), de informalização do processo penal (Azevedo, 2003) e da legislação neocriminalizante (Frade, 2007; Azevedo, 2003; Mendonça 2006). A legislação neocriminalizante expandiu a regulação do Direito Penal a condutas antes não reguladas pela lógica criminalizadora. Em relação a essas normas, sugeri que tanto parlamentares de direita, esquerda quanto a própria sociedade civil reivindicam a resolução penal para determinados conflitos societais na "busca" de efetivar e garantir direitos, sobretudo, de setores descriminados historicamente.

Os dados ainda apontam que 10 leis possuem as duas tendências aqui assinaladas: as leis mistas. A Lei Maria da Penha é um exemplo dessa combinação, assim como a nova Lei de Drogas de 2006 - no 11.343, de 2006 -, que, em diferentes artigos, criminalizaram e/ou puniram mais pesadamente determinadas condutas. Além disso, a Lei Maria da Penha e a nova Lei de Drogas, de 2006, despenalizaram condutas (usuário de drogas) ou as medidas de prevenção, educativas e de proteção à integridade física da mulher. Tais respostas formam atualmente um tipo de oposição identitária entre aqui/ lá; nós/eles; trabalhadores/bandidos ${ }^{32}$; meninos/lobos que se articula com a "sensibilidade" (inflamada) pela opinião pública em demandas por "ordem" que, por conseguinte, pressionam respostas governamentais em políticas de segurança pública.

Portanto, juntamente com o processo legislativo, o objetivo da pesquisa foi analisar as direções mais gerais da punição da legislação brasileira. A questão mais geral do texto foi colocada em termos de princípios hierárquicos que coexistem com princípios universalistas. Essa dissonância, assim, não

32 Sobre a discussão dessas categorias no contexto brasileiro, mais especificamente na cidade de São Paulo, ver os trabalhos de Caldeira (2003) e Feltran (2008). 
opera apenas entre a "Casa e a Rua", mas também na própria formulação e aplicação de normas e dispositivos, já que a aplicação dessas normas (e o sujeito objeto destas) se dá de forma extremamente hierarquizada de acordo com a classe, o grupo e o status social de cada criminalizado ou vitimizado.

Assim, as combinações na política criminal entre criminalização de novas condutas/recrudescimento penal/ampliação de direitos evidenciam um quadro mais complexo de respostas da política criminal do Estado brasileiro pós-1988. Pensei tal variedade de respostas do Parlamento mais no sentido de essas tendências se complementarem e coexistirem e menos no sentido de serem políticas ou tendências contraditórias ${ }^{33}$.

Há de se pensar, num contexto de desigualdade de direitos e de exclusão cultural e institucional, em quais "tipos sociais" são os objetos preferenciais das agências estatais de administração de justiça criminal que encontram diferentes (e desiguais) modalidades de aplicação da lei, em casos específicos, nas relações entre as instituições estatais e os autores de atos ilícitos; em especial, sobre as camadas mais pobres da população, subjetivadas por velhas e novas formas de incriminações que acionam não somente a burocracia estatal, mas os mais diferentes dispositivos de segurança nas práticas sociais da vida cotidiana.

\section{Referências}

ADORNO, Sergio (2003). "Lei e ordem no segundo governo FHC". Tempo Social, v. 15, n. 2, p. 103-41.

AGAMBEN, Giorgio (2004). Estado de exceção. São Paulo: Boitempo.

ALVAREZ, Marcos César (2002). "A criminologia no Brasil ou: Como tratar desigualmente os desiguais". Dados, v. 45, n. 4, p. 677-704.

(2010). "Uma história da violência nas prisões brasileiras", em MAIA, Clarisse Nunes; BRETAS, Marcos Luiz; COSTA, Marcos \& SÁ NETO, Flávio de (orgs.). História das prisões no Brasil. Rio de Janeiro: Rocco, 2010.

AZEVEDO, Rodrigo Ghiringhelli de (2001). "Juizados Especiais Criminais:

\footnotetext{
Sobre esta questão, cito Foucault:"(...) embora esse liberalismo não seja tanto o imperativo da liberdade, mas a gestão e a organização das condições graças às quais podemos ser livres, vocês veem que se instaura, no cerne dessa prática liberal, uma relação problemática, sempre diferente, sempre móvel, entre a produção da liberdade e aquilo que, produzindo-a, pode vir a limitá-la e a destruí-la" (2008, p. 87).
} 
uma abordagem sociológica sobre a informalização da justiça penal no Brasil". Revista Brasileira de Ciências Sociais, v. 16, n. 47, p. 97-182. (2003). Tendências do controle penal na modernidade periférica: as reformas penais no Brasil e na Argentina na última década. Tese (Doutorado em Sociologia). Porto Alegre: Instituto de Filosofia e Ciências Humanas, Universidade Federal do Rio Grande do Sul. BOURDIEU, Pierre (1997). Sobre a televisão. Rio de Janeiro: Jorge Zahar. (1998). A economia das trocas lingüísticas. São Paulo: Editora USP. CALDEIRA, Teresa Pires do Rio (2003). Cidade de muros. São Paulo: Editora USP.

CAMPOS, Marcelo da Silveira (2009). "Mídia e política: a construção da agenda nas propostas de redução da maioridade penal na Câmara dos Deputados". Opinião Pública, v. 15, p. 478-509.

(2010). Crime e Congresso Nacional: uma análise da política criminal aprovada de 1989 a 2006. São Paulo: IBCCRIM, 2010.

CANO, Ignacio (2006). Mensurando a impunidade no sistema de justiça criminal no Rio de Janeiro. Brasília: SENASP.

CHAMPAGNE, Patrick (1996). Formar a opinião: o novo jogo político. Petrópolis: Vozes.

CHEIBUB, José Antônio; FIGUEIREDO, Argelina \& LIMONGI, Fernando (2009). "Partidos políticos e governadores como determinantes do comportamento legislativo na Câmara dos Deputados, 1988-2006”. Dados, v. 52, n. 2, p. 263-99.

FELTRAN, Gabriel (2008). Fronteiras de tensão: um estudo sobre política e violência nas periferias de São Paulo. Tese (Doutorado em Ciências Sociais). Campinas: Programa de Pós-Graduação em Ciências Sociais, Universidade Estadual de Campinas.

FOUCAULT, Michel (2008). Nascimento da biopolítica. São Paulo: Martins Fontes.

FRADE, Laura (2007). O que o Congresso Nacional brasileiro pensa sobre a criminalidade. Tese (Doutorado em Sociologia). Brasília: Departamento de Sociologia, Universidade de Brasília.

GARLAND, David (2001). La cultura del control: crimen y orden social en la sociedad contemporánea. Barcelona: Gedisa.

GINSBERG, Benjamin (1986). The captive public: how mass opinion promotes State power. New York: Basic Books. 
HABERMAS, Jürgen (2003). Mudança estrutural da esfera pública. Rio de Janeiro: Tempo Brasileiro.

KANT DE LIMA, Roberto (1999). "Polícia, justiça e sociedade no Brasil: uma abordagem comparativa dos modelos de administração de conflitos no espaço público". Revista de Sociologia e Política, n. 13, p. 23-38.

(1996). "A administração dos conflitos no Brasil: a lógica da punição", em VELHO, Gilberto \& ALVITO, Marcos. Cidadania e violência. Rio de Janeiro: Editora UFRJ, Editora FGV.

LEMOS, Leany Barreiro de Sousa (2001). “O Congresso brasileiro e a distribuição de benefícios sociais no período 1988-1994: uma análise distributivista”. Dados, v. 44, n. 3, p. 561-605.

LIMONGI, Fernando \& FIGUEIREDO, Argelina (1994). "O processo legislativo e a produção legal no congresso pós-constituinte”. Novos Estudos CEBRAP, n. 38, p. 24-37.

MENDONÇA, Nalayne (2006). Penas e alternativas: um estudo sociológico dos processos de agravamento das penas e de despenalização no sistema de criminalização brasileiro (1984-2004). Tese (Doutorado em Sociologia e Antropologia). Rio de Janeiro: Programa de Pós-Graduação em Sociologia e Antropologia, Universidade Federal do Rio de Janeiro.

MENEGUELLO, Rachel (1998). Partidos e governos no Brasil contemporâneo (1985-1997). São Paulo: Paz e Terra.

MIGUEL, Luis Felipe (2002). "Os meios de comunicação e a prática política”. Lua Nova, n. 55-6, p. 155-84.

NICOLAU, Jairo (1991) "O sistema eleitoral brasileiro: a questão da proporcionalidade da representação política e seus determinantes”, em LIMA JUNIOR, Olavo Brasil de (org.). Sistema eleitoral brasileiro: teoria e prática. Rio de Janeiro: IUPERJ, Vértice.

(1997). "As distorções na representação dos estados na Câmara dos Deputados brasileira”. Dados, Rio de Janeiro, v. 40, n. 3, p. 441-64.

OBSERVATÓRIO DE SEGURANÇA PÚBLICA (OSP/UNESP) (s.d.). Onda de sequestros. Disponível em: http://www.observatoriodeseguranca.org/ imprensa/sequestros. Acessado em: 15 set. 2012.

PIERUCCI, Antônio Flavio (1999). Ciladas da diferença. São Paulo: 34.

RIBEIRO, Ludmila (2009). Administração da justiça criminal na cidade do Rio de Janeiro: uma análise dos casos de homicídio. Tese (Doutorado em Sociologia). Rio de Janeiro: Instituto Universitário de Pesquisas do Rio 
de Janeiro (IUPERJ).

RICCI, Paolo (2006). De onde vêm nossas leis?: origem e conteúdo da legislação em perspectiva comparada. Tese (Doutorado em Ciência Política). São Paulo: Departamento de Ciência Política, Faculdade de Filosofia, Letras e Ciências Humanas, Universidade de São Paulo.

RODRIGUES, Leôncio Martins (2002). Partidos, ideologia e composição social. São Paulo: Editora USP.

SANTOS, Wanderley Guilheme (1998). Décadas de espanto e uma apologia democrática. Rio de Janeiro: Rocco.

(1997). "Representação, proporcionalidades e democracia". Estudos Eleitorais, v. 1, n. 1, p. 179-214.

TEIXEIRA, Alessandra (2006). Do sujeito de direito ao Estado de exceção: $o$ percurso contemporâneo do sistema penitenciário brasileiro. Dissertação (Mestrado em Sociologia). São Paulo: Departamento de Sociologia, Faculdade de Filosofia, Letras e Ciências Humanas, Universidade de São Paulo.

VARGAS, Joana \& MENDONÇA, Ludmila (2008). "Estudos de fluxo da justiça criminal: balanço e perspectivas", em Encontro Anual da ANPOCS, 32, Caxambu. Anais do $32^{\circ}$ Encontro Anual da ANPOCS. Caxambu: ANPOCS.

WACQUANT, Loic (2001). As prisões da miséria. Rio de Janeiro: Jorge Zahar. (2002). "A ascensão do Estado penal nos EUA". Discursos Sediciosos, ano 7, n. 11, p. 13-39.

WAISELFISZ, Julio (2008). Mapa da violência dos municípios brasileiros. Brasília: Ministério da Justiça, RITLA, Instituto Sangari, Ministério da Saúde/Brasília. Disponível em: http://pdba.georgetown.edu/Security/ citizensecurity/brazil/documents/Mapaviolencia.pdf. Acessado em: 20 out. 2012.

(2004). Mapa da violência IV: os jovens do Brasil. Brasília: UNESCO, Instituto Ayrton Senna, Secretaria Especial dos Direitos Humanos. Disponível em: http://unesdoc.unesco.org/ images/0013/001351/135104porb.pdf. Acessado em: 15 jan. 2010.

(2011). Mapa da violência 2012: os novos padrões da violência homicida no Brasil. São Paulo: Instituto Sangari. Disponível em: http:// mapadaviolencia.org.br/pdf2012/mapa2012_web.pdf. Acessado em: 5 fev. 2013. 


\section{Anexo}

\section{Quadro 1 - Leis aprovadas dos partidos de esquerda (1989-2006)}

\begin{tabular}{|c|c|c|c|}
\hline número da lei & conteúdo & partido/estado & autor \\
\hline $\begin{array}{r}10.778 \\
\text { de } 2003 \\
\end{array}$ & $\begin{array}{l}\text { Estabelece a notificação compulsória } \\
\text { da violência contra a mulher. }\end{array}$ & $P C d o B-P A$ & $\begin{array}{l}\text { Dep. Socorro } \\
\text { Gomes }\end{array}$ \\
\hline $\begin{array}{c}\text { 7.716, } \\
\text { de } 1989\end{array}$ & Define os crimes resultantes de preconceito de raça ou de cor. & PDT-RJ & $\begin{array}{l}\text { Dep. Carlos } \\
\text { Alberto Cao }\end{array}$ \\
\hline $\begin{array}{c}9.695 \\
\text { de } 1998\end{array}$ & $\begin{array}{l}\text { torna crime hediondo a falsificação, corrupção, adulteração ou alteração } \\
\text { de produto destinado a fins terapêuticos ou medicinais. }\end{array}$ & PDT-MG & $\begin{array}{l}\text { Dep. Silvio } \\
\text { Abreu }\end{array}$ \\
\hline $\begin{array}{c}8.653, \\
\text { de } 1993\end{array}$ & $\begin{array}{l}\text { Dispõe sobre o transporte de presos: "Art. } 1^{0} \text { É proibido o transporte de } \\
\text { presos em compartimento de proporções reduzidas, com ventilação } \\
\text { deficiente ou ausência de luminosidade." }\end{array}$ & PSB-RJ & $\begin{array}{l}\text { Sen. Jamil } \\
\text { Haddad }\end{array}$ \\
\hline $\begin{array}{c}9.520 \\
\text { de } 1997\end{array}$ & $\begin{array}{l}\text { Revoga dispositivos do Decreto-Lei n 3.689, de } 3 \text { de outubro de } 1941 \\
\text { - Código de Processo Penal, referentes ao exercício do direito de queixa } \\
\text { pela mulher. }\end{array}$ & PSB-AP & $\begin{array}{l}\text { Dep. Raquel } \\
\text { Capiberibe }\end{array}$ \\
\hline $\begin{array}{r}9.975 \\
\text { de } 2000\end{array}$ & $\begin{array}{c}\text { Acrescenta artigo ao ECA:"Tipifica a conduta de } \\
\text { manter casa de exploração sexual infanto-juvenil." }\end{array}$ & PSB-SP & $\begin{array}{l}\text { Dep. Luiza } \\
\text { Erundina }\end{array}$ \\
\hline $\begin{array}{r}10.258, \\
\text { de } 2001 \\
\end{array}$ & $\begin{array}{l}\text { Concede prisão especial dos oficiais das Forças Armadas e os } \\
\text { militares dos Estados, do Distrito Federal e dos Territórios. }\end{array}$ & PSB-RJ & $\begin{array}{c}\text { Dep. Paulo } \\
\text { Baltazar }\end{array}$ \\
\hline $\begin{array}{c}\text { 9.046, } \\
\text { de } 1995\end{array}$ & $\begin{array}{c}\text { Os estabelecimentos penais destinados a mulheres serão } \\
\text { dotados de berçário, e haverá instalação destinada a estágio } \\
\text { de estudantes universitários }\end{array}$ & PT-RJ & $\begin{array}{l}\text { Dep. Benedita } \\
\text { da Silva }\end{array}$ \\
\hline $\begin{array}{c}9.459 \\
\text { de } 1997\end{array}$ & $\begin{array}{l}\text { Altera os arts. } 1^{\circ} \text { e } 20 \text { da Lei no } 7.716 \text {, de } 5 \text { de janeiro de 1989, } \\
\text { que define os crimes resultantes de preconceito de raça ou de cor, } \\
\text { estabelecendo pena de } 1 \text { a } 3 \text { para } 0 \text { crime de discriminação racial, } \\
\text { social etc. (antes a pena era de } 2 \text { a } 5 \text { anos). }\end{array}$ & PT-RS & $\begin{array}{l}\text { Dep. Paulo } \\
\text { Paim }\end{array}$ \\
\hline $\begin{array}{c}\text { 9.777, } \\
\text { de } 1998\end{array}$ & $\begin{array}{l}\text { Define como crimes condutas que favorecem ou configuram trabalho } \\
\text { forçado e escravo. }\end{array}$ & PT-PA & Dep. Paul Rocha \\
\hline $\begin{array}{l}\text { 9.807, } \\
\text { de } 1999\end{array}$ & $\begin{array}{l}\text { Estabelece normas para a organização e a manutenção de programas } \\
\text { especiais de proteção a vítimas e a testemunhas ameaçadas, institui } 0 \\
\text { Programa Federal de Assistência a Vítimas e a Testemunhas Ameaçadas. }\end{array}$ & PT-PE & $\begin{array}{l}\text { Dep. } \\
\text { Humberto Costa }\end{array}$ \\
\hline $\begin{array}{r}10.224 \\
\text { de } 2001\end{array}$ & $\begin{array}{l}\text { Altera o Decreto-Lei n² 2.848, de } 7 \text { de dezembro de } 1940 \text { - Código } \\
\text { Penal, para dispor sobre } 0 \text { crime de assédio sexual. }\end{array}$ & PT-SP & $\begin{array}{l}\text { Dep. lara } \\
\text { Bernardi }\end{array}$ \\
\hline $\begin{array}{r}10.764, \\
\text { de } 2003\end{array}$ & $\begin{array}{l}\text { Altera o ECA - aumenta as penas para os crimes de pedofilia } \\
\text { no ECA, fornecimento ou venda de arma, munição ou explosivo } \\
\text { e drogas entre outros. }\end{array}$ & PT-AC & $\begin{array}{l}\text { Sen. Marina } \\
\text { Silva }\end{array}$ \\
\hline 10.886 , de 2004 & Criando o tipo especial denominado "violência doméstica”. & PT-SP & Dep. lara Bernardi \\
\hline $\begin{array}{l}11.106, \\
\text { de } 2005\end{array}$ & $\begin{array}{l}\text { Excluindo o termo "honesta" nos crimes de rapto e posse sexual mediante } \\
\text { fraude; penalizando o agente pela prática de sequestro e cárcere privado } \\
\text { quando a vítima é companheiro ou maior de } 60 \text { (sessenta anos) ou menor } \\
\text { de } 18 \text { (dezoito) anos, e se o crime é praticado com fins libidinosos; tipi- } \\
\text { ficando os crimes de atentado ao pudor, tráfico internacional de pessoas } \\
\text { e tráfico interno de pessoas; alterando o título do Código Penal para "Do } \\
\text { Lenocínio e do Tráfico de Pessoas". }\end{array}$ & PT-SP & $\begin{array}{l}\text { Dep. lara } \\
\text { Bernardi }\end{array}$ \\
\hline
\end{tabular}

Fonte: Dados de 1989 a 2006. Construído a partir das informações disponíveis na Câmara dos Deputados, Senado Federal, Presidência da República e Ministério da Justiça do Brasil. 


\section{Quadro 2 - Leis aprovadas dos partidos de centro}

\begin{tabular}{|c|c|c|c|}
\hline$n^{0}$ da lei & conteúdo & $\begin{array}{l}\text { partido/ } \\
\text { estado }\end{array}$ & autor \\
\hline $\begin{array}{c}\text { 9.281, } \\
\text { de } 1996\end{array}$ & $\begin{array}{l}\text { Aumenta a pena de reclusão de seis a } 10 \text { anos para os crimes de estupro e ato } \\
\text { libidinoso, se a ofendida é menor de } 14 \text { anos, a violência não é presumida, e se } 0 \\
\text { ofendido é menor de } 14 \text { anos. }\end{array}$ & PSDB-ES & $\begin{array}{l}\text { Dep. Rose } \\
\text { de Freitas }\end{array}$ \\
\hline $\begin{array}{c}\text { 9.521, } \\
\text { de } 1997\end{array}$ & $\begin{array}{l}\text { Descaracteriza como contravenção penal a exploração da credulidade pública me- } \\
\text { diante sortilégios, predição do futuro, explicação de sonho ou praticas congêneres. }\end{array}$ & PSDB-SP & $\begin{array}{l}\text { Dep. Almino } \\
\text { Affonso }\end{array}$ \\
\hline $\begin{array}{r}10.628, \\
\text { de } 2002\end{array}$ & $\begin{array}{l}\text { Concedendo, assim, foro especial de processo e julgamento (foro privilegiado) a } \\
\text { ex-autoridade titular de cargo público. }\end{array}$ & PSDB-MG & $\begin{array}{l}\text { Dep. Bonifácio } \\
\text { de Andrada }\end{array}$ \\
\hline $\begin{array}{r}10.409 \\
\text { de } 2002\end{array}$ & $\begin{array}{l}\text { Dispõe sobre a prevenção, o tratamento, a fiscalização, o controle e a repressão à } \\
\text { produção, ao uso e ao tráfico ilícitos de produtos, substâncias ou drogas ilícitas que } \\
\text { causem dependência física ou psíquica, assim elencados pelo Ministério da Saúde. }\end{array}$ & PSDB-MG & $\begin{array}{l}\text { Dep. } \\
\text { Elias Murad }\end{array}$ \\
\hline $\begin{array}{r}10.826 \\
\text { de } 2003\end{array}$ & $\begin{array}{l}\text { Dispõe sobre registro, posse e comercialização de armas de fogo } \\
\text { e munição, sobre o Sistema Nacional de Armas (SINARM). }\end{array}$ & PSDB-ES & $\begin{array}{c}\text { Sen. } \\
\text { Gerson Camata }\end{array}$ \\
\hline $\begin{array}{l}8.069 \\
\text { de } 1990\end{array}$ & Institui o ECA. & PMDB-MG & $\begin{array}{c}\text { Sen. } \\
\text { Ronan Tito }\end{array}$ \\
\hline $\begin{array}{c}8.701 \\
\text { de } 1993\end{array}$ & $\begin{array}{l}\text { Acrescenta parágrafo ao art. } 370 \text { do Código de Processo Penal: "Consideram-se } \\
\text { feitas as intimações pela simples publicação dos atos no órgão oficial." }\end{array}$ & PMDB-RS & $\begin{array}{l}\text { Dep. Ivo } \\
\text { Mainardi }\end{array}$ \\
\hline $\begin{array}{c}\text { 8.882, } \\
\text { de } 1994\end{array}$ & $\begin{array}{l}\text { Acrescenta parágrafo ao art. } 20 \text { da Lei no } 7.716 \text {, de } 1989 \text {, que "define os crimes } \\
\text { resultantes de preconceitos de raça ou de cor". "§ } 1^{\circ} \text { Incorre na mesma pena quem } \\
\text { fabricar, comercializar, distribuir ou veicular símbolos, emblemas, ornamentos, } \\
\text { distintivos ou propaganda que utilizem a cruz suástica ou gamada, para fins de } \\
\text { divulgação do nazismo." }\end{array}$ & PMDB-SP & $\begin{array}{l}\text { Dep. Alberto } \\
\text { Goldman }\end{array}$ \\
\hline $\begin{array}{c}8.862 \\
\text { de } 1994\end{array}$ & Altera as disposições sobre peritos criminais". & PMDB-MG & $\begin{array}{c}\text { Sen. } \\
\text { Ronan Tito }\end{array}$ \\
\hline $\begin{array}{r}9.099 \\
\text { de } 1995\end{array}$ & Instituiu os Juizados Especiais Criminais. & PMDB-SP & $\begin{array}{c}\text { Dep. } \\
\text { Michel Temer }\end{array}$ \\
\hline $\begin{array}{c}9.034 \\
\text { de } 1995\end{array}$ & $\begin{array}{l}\text { Dispõe sobre a utilização de meios operacionais para a prevenção } \\
\text { e repressão de ações praticadas por organizações criminosas. }\end{array}$ & PMDB-SP & $\begin{array}{l}\text { Dep. } \\
\text { Michel Temer }\end{array}$ \\
\hline $\begin{array}{l}9.033 \\
\text { de } 1995\end{array}$ & $\begin{array}{c}\text { Dá nova redação ao } \S 1^{\circ} \text { do art. } 408 \text { do Código de Processo Penal, sobre a sentença } \\
\text { proferida pelo juiz ao réu. "Art. } 408 \text { - } \S 1^{\circ} \text { Na sentença de pronúncia o juiz declarará } \\
\text { o dispositivo legal em cuja sanção julgar incurso o réu, recomendá-I0-á na prisão } \\
\text { em que se achar, ou expedirá } \\
\text { as ordens necessárias para a sua captura." }\end{array}$ & PMDB-PE & $\begin{array}{l}\text { Dep. Maurilio } \\
\text { Ferreira Lima }\end{array}$ \\
\hline $\begin{array}{l}9.303, \\
\text { de } 1996\end{array}$ & 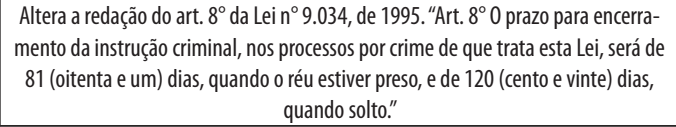 & PMDB-SP & $\begin{array}{l}\text { Dep. } \\
\text { Michel Temer }\end{array}$ \\
\hline $\begin{array}{c}9.460 \\
\text { de } 1997\end{array}$ & $\begin{array}{l}\text { Concede à mulher e ao maior de } 60 \text { anos o direito de estar recolhido separadamen- } \\
\text { te em estabelecimento próprio e adequado a sua condição pessoal. }\end{array}$ & PMDB-AC & $\begin{array}{c}\text { Dep. } \\
\text { Chicão Brigido }\end{array}$ \\
\hline $\begin{array}{r}11.259 \\
\text { de } 2005\end{array}$ & $\begin{array}{l}\text { Determina a investigação imediata em caso de desaparecimento de criança ou } \\
\text { adolescente e a garantia de direitos difusos ou coletivos. }\end{array}$ & PMDB-MG & Dep. Maria Elvira \\
\hline
\end{tabular}

* Ficou assim: "Art. 6. I - dirigir-se ao local, providenciando para que não se alterem o estado e conservação das coisas, até a chegada dos peritos criminais; II - apreender os objetos que tiverem relação com 0 fato, após liberados pelos peritos criminais." "Art. 159. Os exames de corpo de delito e as outras perícias serão feitos por dois peritos oficiais. $§ 1^{0}$ Não havendo peritos oficiais, o exame será realizado por duas pessoas idôneas, portadoras de diploma de curso superior, escolhidas, de preferência, entre as que tiverem habilitação técnica relacionada à natureza do exame. Os peritos elaborarão 0 laudo pericial, onde descreverão minuciosamente o que examinarem, e responderão aos quesitos formulados. Art. 160. Parágrafo único. 0 laudo pericial será elaborado no prazo máximo de 10 dias, podendo este prazo ser prorro- 
gado, em casos excepcionais, a requerimento dos peritos." "'Art. 164. Os cadáveres serão sempre fotografados na posição em que forem encontrados, bem como, na medida do possível, todas as lesões externas e vestígios deixados no local do crime." "Art. 169 - Parágrafo único. Os peritos registrarão, no laudo, as alterações do estado das coisas e discutirão, no relatório, as consequências dessas alterações na dinâmica dos fatos." "Art. 181. No caso de inobservância de formalidades, ou no caso de omissões, obscuridades ou contradições, a autoridade jurídica mandará suprir a formalidade, complementar ou esclarecer o laudo." (Grifos nossos.)

Fonte: Dados de 1989 a 2006. Construído a partir da Câmara dos Deputados, Senado Federal, Presidência da República, Ministério da Justiça do Brasil.

\section{Quadro 3 - Leis aprovadas dos partidos de direita}

\begin{tabular}{|c|c|c|c|}
\hline $\mathrm{n}^{0}$ da Lei & conteúdo & partido/estado & autor \\
\hline $\begin{array}{c}7.871, \\
\text { de } 1989\end{array}$ & Início da Defensoria Pública. & PTB-RJ & $\begin{array}{c}\text { Dep. } \\
\text { Fábio Raunheitti }\end{array}$ \\
\hline $\begin{array}{c}8.072, \\
\text { de } 1990\end{array}$ & Dispõe sobre os crimes hediondos. & PFL-RO & $\begin{array}{c}\text { Sem. } \\
\text { Odacir Soares }\end{array}$ \\
\hline $\begin{array}{c}9.111 \\
\text { de } 1995\end{array}$ & $\begin{array}{l}\text { Dispõe que o desacompanhamento de comprovação de } \\
\text { procedência de peles ou outros produtos de animais será } \\
\text { caracterizado como contrabando. }\end{array}$ & PTB-RJ & $\begin{array}{c}\text { Sen. } \\
\text { Nelson Carneiro }\end{array}$ \\
\hline $\begin{array}{c}9.080 \\
\text { de } 1995\end{array}$ & $\begin{array}{l}\text { Acrescenta dispositivos às Leis no } 7.492 \text { (Crimes contra o sistema } \\
\text { financeiro), de } 16 \text { de junho de 1986, e no } 8.137 \text { (Crimes contra a ordem } \\
\text { tributária), de } 27 \text { de dezembro de } 1990 .\end{array}$ & PL-SP & $\begin{array}{l}\text { Dep. } \\
\text { Robson Tuma }\end{array}$ \\
\hline $\begin{array}{c}9.061 \\
\text { de } 1995\end{array}$ & $\begin{array}{l}\text { Altera a redação do art. } 809 \text { do Código de Processo Penal, referente } \\
\text { à estatística judiciária criminal }{ }^{8} \text {. }\end{array}$ & PL-MT & $\begin{array}{l}\text { Dep. Wellington } \\
\text { Fagundes }\end{array}$ \\
\hline $\begin{array}{c}9.318 \\
\text { de } 1996\end{array}$ & $\begin{array}{c}\text { Altera a alínea h do inciso Il do art. } 61 \text { do Código Penal. "São circunstân- } \\
\text { cias que sempre agravam a pena, quando não constituem ou qualificam } \\
\text { o crime: II - ter o agente cometido crime: (...) h) contra criança, velho, } \\
\text { enfermo ou mulher grávida." }\end{array}$ & PFL-AP & $\begin{array}{l}\text { Dep. } \\
\text { Geovani Borges }\end{array}$ \\
\hline $\begin{array}{l}10.803, \\
\text { de } 2003\end{array}$ & $\begin{array}{l}\text { Altera } 0 \text { art. } 149 \text { do Decreto-Lei n } 2.848 \text {, de } 7 \text { de dezembro de } 1940 \text { - } \\
\text { Código Penal, para estabelecer penas ao crime nele tipificado e indicar as } \\
\text { hipóteses em que se configura condição análoga à de escravo. }\end{array}$ & PFL-DF & $\begin{array}{c}\text { Sen. } \\
\text { Waldeck Ornelas }\end{array}$ \\
\hline $\begin{array}{l}11.313, \\
\text { de } 2006\end{array}$ & $\begin{array}{c}\text { Compete ao Juizado Especial Federal Criminal processar e julgar } \\
\text { os feitos de competência da Justiça Federal e Estadual relativos às } \\
\text { infraçōes de menor potencial ofensivo, respeitadas as regras de c } \\
\text { onexão e continência. }\end{array}$ & PFL-G0 & $\begin{array}{l}\text { Sen. } \\
\text { Demóstenes Torres }\end{array}$ \\
\hline $\begin{array}{c}9.677, \\
\text { de } 1998\end{array}$ & $\begin{array}{l}\text { Inclui na classificação dos delitos considerados hediondos crimes } \\
\text { contra a saúde pública. }\end{array}$ & PPB-DF & $\begin{array}{l}\text { Dep. Benedito } \\
\text { Domingos }\end{array}$ \\
\hline $\begin{array}{l}10.713 \\
\text { de } 2003\end{array}$ & $\begin{array}{c}\text { Dispõe sobre a emissão anual de atestado de pena a cumprir - tornando } \\
\text { direito do preso o atestado de pena com o tempo determinado a cumprir, } \\
\text { a ser emitido, anualmente, pelo juiz de execução penal. }\end{array}$ & PP-RR & $\begin{array}{l}\text { Dep. } \\
\text { Ricardo Barros }\end{array}$ \\
\hline
\end{tabular}

* "Art. $1^{\circ} 0 \S 2^{\circ}$ do art. 809 do Decreto-Lei n 3.689, de 3 de outubro de 1941 - Código de Processo Penal, passa a vigorar com a seguinte redação: Art. 809 (...) § $2^{\circ}$ Esses dados serão lançados semestralmente em mapa e remetidos ao Serviço Estatística Demográfica Moral e Política do Ministério da Justiça."

Fonte: Dados de 1989 a 2006. Construído a partir da Câmara dos Deputados, Senado Federal, Presidência da República e Ministério da Justiça do Brasil. 


\section{Resumo}

O presente artigo analisa as principais leis aprovadas em segurança pública e justiça criminal no Congresso Nacional brasileiro entre 1989 e 2006. A pesquisa divide-se em dois momentos: 1) mapeamento do material apontando os partidos, estados e casas proponentes; mandatos presidenciais que sancionaram as leis; número de leis aprovadas por ano e o tempo médio de tramitação das leis de acordo com a casa propositora; 2) os tipos gerais (modelos) de punição propostos pelas normas. Proponho a partir do material apresentado que a política de segurança pública no Brasil está em uma disputa na qual coexistem leis que criminalizam novas condutas, leis que recrudescem a punição em relação a um referencial anterior e leis que despenalizam condutas ou buscam efetivar direitos e garantias fundamentais dos acusados.

Palavras-chaves: Congresso Nacional, legislação, segurança pública, justiça criminal.

\section{Abstract}

This paper analyzes the main laws on public safety and criminal justice approved by the Brazilian National Congress in 1989-2006. The research is divided into two different moments: 1) mapping material indicating which are the proponent parties, states, houses; Presidents who sanctioned the laws; number of laws adopted per year and the average time they were debated in Congress according to the proponent house; 2 ) general types (models) of punishment proposed by those laws. Based on the material presented, I propose that there Brazilian criminal policy undergoes a dispute which includes coexistence laws criminalizing new disputes, laws establishing harsher punishment regarding previous references, and laws de-criminalizing conducts or seeking to set rights and guarantees for defendants.

Keywords: Brazilian National Congress, law, public safety, criminal justice.

Recebido em 10 de abril de 2013.

Aprovado em 20 de janeiro de 2014. 